\title{
Imperatyw pedagogiczny jako element strategii wychowawczej
}

\author{
Pedagogical Imperative as an Element
} of Educational Strategy

\begin{abstract}
ABSTRAKT
Artykuł ma na celu ukazanie różnic pomiędzy kategoriami pedagogicznymi rygoryzmu i liberalizmu wychowawczego, określić treść i zakres znaczeniowy tych pojęć oraz uzasadnić ich miejsce w strategiach wychowawczych oraz w ich różnych typach. Stąd posłużono się w artykule syntetycznym ujęciem historycznym, które ma w sposób jak najbardziej lapidarny ukazać rozwój myśli dotyczq̨cej przymusu i swobody w wychowaniu, a zwłaszcza przejawów praktyki w tym zakresie od starożytności aż po czasy nowożytne. Przeprowadzono także analizę dwóch sprzecznych koncepcji pedagogicznych, które ujmuje się w relacji homo educandus vs homo non educandus. Koncepcje te w różny sposób odwołuja się do takiej kategorii, jak wolność pedagogiczna i określaja jej znaczenie w praktyce wychowawczej. Takie podejście umożliwiło przeprowadzenie typologizacji dwóch strategii wychowawczych, które ujęto w dwie kategorie: strategii autokratycznej i strategii formacyinej. W każdej z nich pojawia się problem odwoływania się do wybranych imperatywów pedagogicznych, które zostały szczegółowo opisane. Do nich zaliczono: posłuszeństwo, dyscyplinę, karność, odpowiedzialność oraz sumienność. Ukazano także ich zwiqzek z procesem kształtowania w postawach wychowanków sprawności, zwłaszcza sprawności moralnych, kłóre

SLOWA KLUCZOWE rygoryzm, liberalizm, imperatyw wychowawczy, strategia wychowawcza, posłuszeństwo, dyscyplina, karność, odpowiedzialność, sumienność

KEYWORDS rigorism, liberalism, educational imperative, educational strategy, obedience, discipline, responsibility, conscientiousness

SPI Vol. 20, 2017/2

ISSN 2450-5358

e-ISSN 2450-5366 DOI: 10.12775/SPI.2017.2.002

Artykuły i rozprawy


należy pojmować jako element rezultatu procesu wychowawczego. Imperatywy pedagogiczne, do których odwołuja się wychowujący, moga świadczyć o poziomie świadomości wychowawczej i kulturze pedagogicznej tych, którzy przyimują na siebie odpowiedzialność za wychowanie młodzieży. Rolq imperatywów pedagogicznych jest wspomaganie wychowanków w ich osobistym i społecznym rozwoju.

\section{ABSTRACT}

The purpose of the article is to outline the differences between such pedagogical categories as: rigorism and liberalism of upbringing, assessing the content, range of meaning of terms and providing legitimacy for them in strategies of upbringing and their different types. Thus, a historical synthetic view is applied that should show, in a lapidary way, the development of thought connected to constraint and liberty in upbringing and in particular the symptoms of practice in that range from antiquity to modern times. Moreover, the analysis of two inconsistent pedagogical conceptions was conducted that are subsumed in the relation homo educandus vs. homo non educandus. These conceptions, in different ways, refer to such categories as pedagogical freedom and determine their meaning to education. This approach allowed two types of educational strategies to emerge that are presented in two categories: autocratic strategy and formation strategy. In each of them there is a problem referring to selected pedagogical imperatives that have been described in detail. These include: obedience, discipline, respect for punishment, responsibility and conscientiousness. It also shows their relation with the process of shaping attitudes to learner efficiency, especially the efficiency of morality which should be understood as an element of the result of the educational process. Pedagogical imperatives to that the educators referred to can indicate the level of awareness of the educational and pedagogical culture of those who assume responsibility for the education of youth. The role of pedagogical imperatives is to support learners in their personal and social development. 
Skądże u nas początek brać mają domowe cnoty, uczucie obowiązku, prawdziwa bogobojność, jeżeli sami rodzice w serca dzieci tych przymiotów nie wpajają. E. Estkowski, Jakie powinno być wychowanie mtodzieży, s. $68^{1}$.

\section{Między rygoryzmem a liberalizmem wychowawczym}

Przymus i swoboda w wychowaniu to kategorie, które należą do zagadnień przed jakimi od zawsze stawali zarówno zajmujący się problematyką teoretyczną w pedagogice, jak i bezpośrednio uczestniczący w procesach wychowawczych. Historia wychowania i myśli pedagogicznej dobitnie pokazuje jak na przestrzeni wieków odnoszono się do rygoryzmu i liberalizmu wychowawczego, jakie zajmowano stanowisko i jak uzasadniano poglądy ich przeciwników bądź zwolenników, jak te poglądy radykalnie się zmieniały lub ewaluowały w różnych epokach.

W starożytnych poglądach i praktykach pedagogicznych spotykamy się zarówno z rygoryzmem, jak i liberalizmem wychowawczym. Rygoryzm w postaci rozkazów i kar stanowił podstawę wychowania spartańskiego, którego celem było osiągnięcie samodyscypliny młodzieży mającej być zawsze gotową do walki. Jak podkreślał Stanisław Kot, surowa dyscyplina moralna przysposabiała typ obywatela spartańskiego, który z czasem stawał się szanowanym obywatelem w całej Grecji: obojętność na wygody ciała, pogarda dla miękkości i zniewieściałości, hart w cierpieniach, niewzruszona odwaga w niebezpieczeństwach, trzeźwość i skromność - oto cechy zdobywane przez surowe wychowanie koszarowe ${ }^{2}$.

Ateński pedagog-niewolnik miał prawo korzystania z rózgi, która była symbolem jego władzy nad wychowankiem. Dominował powszechny pogląd, że: „kto nie brał kijów, nie mógł otrzymać dobrego

1 Ewaryst Estkowski (1820-1856), wielkopolski działacz oświatowy, nauczyciel, publicysta, od 1847 roku nauczyciel seminarium nauczycielskiego w Poznaniu, założyciel Towarzystwa Pedagogicznego (1848-1853), wydawca pierwszego czasopisma pedagogicznego pt. „Szkoła Polska” i współwydawca „Pisma dla Nauczycieli Ludu i Ludu Polskiego”, redaktor „Szkółki dla Dzieci i Szkółka dla Młodzieży”.

2 S. Kot, Historia wychowania. Zarys podręcznikowy, Kraków 1924, s. 21. 
wychowania”3. Kary, bicie i chłosta były rozpowszechnionymi środkami wychowawczymi. Do wymierzania kary chłosty angażowano kilku chłopców, którzy winowajcę zawieszali na swych ramionach. Nie tylko stosowali je nauczający, ale także rodzice, o czym dowiadujemy się z dzieła Bakałarz. Mimus Herondasa $a^{4}$ Rodzice nie rozczulali się nad dzieckiem, a surowe kary fizyczne uważali za niepodlegający krytyce doskonały środek wychowawczy.

W epoce hellenistycznej (grecko-rzymskiej, po upadku Hellady) karność nie zelżała, a wręcz została zaostrzona. Interesujący opis w tej kwestii przedstawia filozof Teles:

Zaledwie wyjdzie chłopiec $\mathrm{z}$ rąk piastunki, zajmuje się nim pedagog, pedotriba, gramatysta, lutnista i rysownik. $Z$ czasem przychodzi do tego nauczyciel rachunków, miernictwa, i ujeżdżacz koni. Skoro świt, musi się zrywać z pościeli, nigdy nie ma wolnej godziny. Zostawszy efebem, także musi drżeć ze strachu, to przed kosmetą, to pedotribą, przed mistrzem szermierki, przed gimnazjarchą - każdy z nich bije go nadzoruje, zatruwa mu życie. Przejdzie efebię i ma już 20 lat, jeszcze musi się bać i mieć na baczności przed gimnazjarchą i przed dowódcą wojsk ${ }^{5}$.

Starożytny Rzym cechuje rygoryzm wychowawczy. Świadczy o tym fresk z I wieku po Chrystusie przedstawiający scenę karności w szkole. J. Kot ujął ją w następującym opisie:

Trzech uczniów siedzi na ławce, długie włosy spadają na tunikę, która ich aż do stóp okrywa, na kolanach trzymają zwoje, w których się uważnie rozczytują. Przed nimi przechadza się osobistość wyprostowana, twarz okala silny zarost, ręce schowane, $w$ ciemno-czerwonym płaszczu - po surowej, a złośliwej minie poznać, że to nauczyciel. Na drugiej stronie obrazu odbywa się wymierzanie sprawiedliwości. Nieszczęsny uczeń prawie cały do naga rozebrany leży na plecach kolegi, który go silnie obydwu rękoma przytrzymuje; drugi, przykląkłszy, schwycił go za nogi, aby nie mógł drgnąć. $Z$ boku pomocnik nauczyciela podniósł rózgę do ciosów, a pozycja jego świadczy, że rózga spada na plecy biedaka z wielkim rozmachem, bolesność jej razów znać też z rozpaczliwej miny, $\mathrm{z}$ rozwartych do krzyku ust bitego. $Z$ tyłu nadchodzi jeszcze jedna postać, przynosząc świeżą rózgę́

3 Por. M. Mitek, Pedagogika dla teologów, Wrocław 2002, s. 22.

4 Por. J. Czubek, Wybór dziet pisarzy greckich i tacinsskich, Lwów 1902.

5 Cyt. za J. Kot, Historia wychowania, dz. cyt., s. 66.

6 Tamże, s. 86. 
Opis ten utwierdza nas w przekonaniu, że w świecie późnej starożytności dominował rygoryzm pedagogiczny, co potwierdza starorzymska praktyka i poglądy na wychowanie. Posłużmy się wypowiedzią św. Augustyna (354-430), który jako dorosły mężczyzna wspominał swoje perturbacje edukacyjne w sposób następujący:

Oddano mnie do szkoły, abym się uczył liter, chociaż jeszcze nie wiedziałem jaki z tego wyniosę pożytek, a przecież, gdy się opieszale uczyłem, karano mnie biciem [...] mały, ale nie z małem uczuciem błagałem Ciebie, Boże, aby mnie w szkole nie bito. A kiedyś mych próśb nie słuchał [...] śmiali się starsi, nawet rodzice, którzy mi przecież niczego złego nie życzyli, śmiali się z tych plag moich, wielkiego i ciężkiego naówczas nieszczęścia mego ${ }^{7}$.

Jadwiga Bińczycka w książce Między swobodq a przemocq w wychorwaniu odwołuje się do życiorysu św. Augustyna, który skarżył się w nim na potworny lęk przed nauczycielem bijącym go niemiłosiernie ${ }^{8}$.

Średniowiecze zapamiętane zostało $\mathrm{z}$ tego, że rygoryzm wychowawczy dominował zarówno w rodzinach, jak i szkołach, a kara fizyczna była powszechnie stosowanym środkiem pedagogicznym. Dowodzi tego rozprawa Wincentego z Beauvais zatytułowana $O$ wychowaniu dzieci królewskich (1245), w której podaje „Dziewięć przyczyn, dla których chętnie należy przyjmować karę"”.

Z krytyką stosowania rygoryzmu wychowawczego wystąił w czasach odrodzenia Erazm z Rotterdamu, który w Pochwale gtupoty mówił o gramatykach w sposób następujący: „tacy oni z siebie radzi, kiedy zastrachaną trzódkę w przerażenie wprawiają groźną miną i głosem, kiedy kijem, rózgą, rzemieniem łupią skórę biednych dzieci i na wszelkie sposoby srożą się, jak im tylko przyjdzie ochota" ${ }^{10}$.

Założyciel nadwornej szkoły w Mantui, Vittorino da Feltre (1378-1446), był zdecydowanym przeciwnikiem surowej i ascetycznej atmosfery średniowiecznych metod wychowawczych. Starał się

7 Tamże.

8 J. Bińczycka, Między swoboda a przemoca w wychowaniu, Kraków 1999, s. 21.

9 Wybór tekstów źródtowych do historii wychowania. Wyboru dokonali J. Walczyna, S. Wołoszyn, Warszawa 1962, s. 29.

10 Erazm z Rotterdamu, Pochwata gtupoty, w: Źródta do dziejów wychowania i myśli pedagogicznej, t. 1, Wyboru dokonał i opracował S. Wołoszyn, Warszawa 1965, s. 220. 
w swoim postępowaniu pedagogicznym usunąć wszelką grozę, zastraszanie i przymus względem uczniów. Naczelną zasadą jego działalności wychowawczej było otoczenie ich ojcowską życzliwością i przyjacielską opieką. Wpajał im ambicję i budził nadzieje na przyszłość, apelował do honoru osobistego ucznia. Szkołę tę nazwał Casa Giocosa (Dom Radości), nie stosowano w niej żadnego przymusu ani kar fizycznych ${ }^{11}$.

W epoce odrodzenia i humanizmu, czyli od XVI wieku, narasta próba uwolnienia się w wychowaniu i edukacji od opresyjnych metod pedagogicznych, wśród których dominowało karanie ucznia. Idee emancypacji towarzyszyły wielu reformatorom kształcenia dzieci i młodzieży przez cały wiek XVII, XVIII oraz XIX. Rezultaty upowszechnienia tych idei były wówczas zaledwie skromne.

Ale jeszcze w czasach oświecenia Stanisław Konarski (1700-1773) mówił o szkołach jako o katowniach, jatkach dziecięcych, a nauczycieli nazywał bitnikami, dzierżykijami, katami, a nawet rzeźnikami ${ }^{12}$.

Jean Jacques Rousseau (1712-1778) to jeden z najwybitniejszych pisarzy i myślicieli francuskich epoki oświecenia. Jest on autorem powszechnie znanej rozprawy Emil, czyli o wychowaniu (1762), w której przedstawił własny pogląd na system wychowania naturalnego. Polegać miał on na swobodnym rozwoju natury ludzkiej i w związku z tym nie należało - zdaniem tego myśliciela - stawiać dzieciom żadnych celów, a jedynie wykorzystywać ich naturalne umiejętności życiowe, które są właściwościami i zarazem umiejętnościami życiowymi każdego człowieka. Do nich zaliczał: działanie, używanie wszystkich zmysłów i wykorzystywanie zdolności. Rousseau stał na stanowisku, że wychowanie musi być dostosowane do wieku dziecka, musi uwzględniać jego rozwój fizyczny i umysłowy, a wychowawca winien uczyć się postępowania dziecka i zostawiać mu swobodę oraz przyzwyczajać równocześnie do zdyscyplinowanej samodzielności ${ }^{13}$.

Ważną rolę $\mathrm{w}$ procesie odchodzenia od rygoryzmu pedagogicznego odegrała w Polsce Komisja Edukacji Narodowej (17731794), która postulowała okazywanie szacunku dla dziecka. Antoni

11 Por. Historia wychowania, t. 1, red. Ł. Kurdybacha, Warszawa 1965, s. 278284.

12 Por. J. Bińczycka, Między swoboda a przemoca w wychowaniu, dz. cyt. s. 21.

13 Por. Historia wychowania, dz. cyt., s. 609-620. 
Popławski, autor książeczek zatytułowanych Moralna nauka (17781786), usiłował w nich przekazać wychowankowi świadomość tego, „jakich należności powinien oczekiwać od rodziców, nauczycieli, społeczeństwa i państwa oraz jakie on ma wobec nich obowiązki, czyli powinności"14. Podobnie Adam Kazimierz Czartoryski w broszurce Katechizm kadecki (1775) starał się uczyć młodzież moralności za pomocą imperatywów odnoszących się do ducha świadomej karności ${ }^{15}$. Treści tych niewielkich książeczek służyć miały zrozumieniu - tak przez dorastających, jak i dorosłych - konieczności odejścia od wypaczonego rygoryzmu wychowawczego i przechodzenia do racjonalnego liberalizmu pedagogicznego. Umiarkowane stanowisko w zakresie stosowania imperatywów wychowawczych prezentował Henryk Pestalozzi (1746-1827), a także wielu innych pedagogów tamtej epoki. Wydaje się z perspektywy czasu, że zmierzano wówczas do pogodzenia dwóch wizji wychowania: rygorystycznej z liberalną.

Na przełomie XIX i XX wieku upominano się i wdrażano w praktykę pedagogiczną ideę wzywającą do rezygnacji z przymusu i opresji wychowawczej, jako wyraźny i zdecydowany sprzeciw wobec tradycyjnej pedagogiki i szkoły herbartowskiej ${ }^{16}$. Liberalizm pedagogiczny uwyraźnił się w poglądach Lwa Tołstoja (1828-1910) z Jasnej Polany, rosyjskiego pisarza zajmującego się działalnością pedagogiczną. $\mathrm{Na}$ pierwszym miejscu stawiał on wszechstronny rozwój człowieka, który można osiągnąć poprzez usunięcie wszelkich niepożądanych wpływów zewnętrznych wraz ze zniesieniem wobec ucznia wszelkiego przymusu. Podobne poglądy głosiła Ellen Key (1848-1926), szwedzka zwolenniczka skrajnie indywidualistycznego wychowania. Dała ona temu wyraz w książce Stulecie dziecka (1900), w której przedstawiła program walki o prawa dziecka do swobodnego rozwoju w zgodzie z naturą. Na gruncie głoszonych przez wspomnianych wyżej pedagogów oraz innych autorów idei pedagogicznych rozwinął się w pierwszym ćwierćwieczu XX stulecia ruch tzw. Nowego Wychowania.

14 Tamże, s. 700.

15 Por. tamże.

16 Por. J. Sobczak, Nowe Wychowanie w polskiej pedagogice okresu drugiej Rzeczypospolitej (1918-1939), Bydgoszcz 1998, rozdz. VI i VII. 
Upowszechniający się liberalizm pedagogiczny leży u podstaw pedagogiki humanistycznej, która domaga się podmiotowego traktowania ucznia podejmującego wysiłek samowychowawczy. Wysiłkowi temu winna towarzyszyć wyrozumiałość i autonomia każdego dziecka. Takie stanowisko dostrzec można w poglądach antropozoficznych Rudolfa Steinera (1861-1925), do których odwołują się organizowane szkoły typu Waldorf, zrzeszające nauczycieli i uczniów, których działalność ma przebiegać w warunkach poszanowania autonomii i w atmosferze bezstresowości.

Można przyjąć założenie, że także w czasach współczesnych, mimo coraz bardziej zobiektywizowanej wiedzy o prawidłowościach i czynnikach rozwojowych dzieci i młodzieży, coraz wyższego poziomu świadomości wychowawczej i kultury pedagogicznej społeczeństwa dorosłych, zagadnienie rygoryzmu i liberalizmu pedagogicznego nie znajduje jednoznacznego rozstrzygnięcia. Pewnie dlatego, że kwestia swobody i przymusu w wychowaniu należy do tych nierozstrzygalnych problemów. Swoboda i przymus wychowawczy są w jakimś stopniu ze sobą nierozerwalnie złączone. Wiedzą o tym zarówno rodzice, nauczyciele, psycholodzy, jak i pedagodzy. Wie o tym każda wspólnota rodzinna, szkolna czy środowiskowa. Mimo tej trudności nie ustają dyskusje pomiędzy zwolennikami i przeciwnikami liberalizmu oraz rygoryzmu wychowawczego.

\section{Homo non educandus vs homo educandus a problem wolności wychowanka}

We współczesnych koncepcjach pedagogicznych, wywiedzionych $\mathrm{z}$ różnych ideologii i doktryn filozoficznych, można dostrzec dwa zasadniczo skrajne podejścia do znaczenia i roli wychowania człowieka. Jedne z nich głoszą, że człowiek jest istotą potrzebującą wychowania (homo educandus), inne powiadają, że człowiek jest istotą niepotrzebująca wychowania (homo non educandus). Do najbardziej wyrazistych koncepcji, które zakładają, że żaden człowiek nie potrzebuje wychowania, że żaden dorosły nie jest odpowiedzialny za dzieci, a kto kocha dzieci, ten ich nie wychowuje, należy z pewnością antypedagogika. Do jej rozwoju przyczyniła się Alice Miller, autorka takich bestsellerów, jak Dramat udanego dziecka (1979), Zniewolone dziecinstwo (1980) i Pamięć wyzwolona (1981). Do przedstawicieli 
tego nurtu należy zaliczyć również Ekkeharda von Braunmühla ${ }^{17}$, Hubertusa von Schonebecka ${ }^{18}$, czy wreszcie Katharinę Rutschky, autorkę książki Czarna pedagogika - teksty źródtowe z historii wychowania obywatelskiego ${ }^{19}$.

Skrajną odmianę liberalizmu pedagogicznego prezentuje Hubertus von Schoenbeck (1947-) niemiecki antypedagog, który zaleca uwolnienie szkół od jakiejkolwiek pedagogiki, a uczniów od wychowania narzuconego im przez rodziców, Kościół, społeczeństwo, a tym bardziej przez państwo.

Koncepcje pedagogiczne, których naczelną dewizą jest teza homo non educandus, w tym antypedagogika, opierają się na przekonaniu mówiącym, że

- „człowiek od narodzenia czuje, co jest dla niego najlepsze: człowiek nie jest istotą wybrakowaną, lecz istotą cudowną (kompetentne dziecko);

- nie istnieje nawet najmniejsza odpowiedzialność za innych, lecz tylko odpowiedzialność za siebie samego: postawa pedagogiczna jest określana jako destruktywna «kradzież odpowiedzialności»;

- młodzież nie potrzebuje wychowania: człowiek nie jest homo educandus;

- akty wychowawcze nie prowadzą do zamierzonego celu;

- dorośli potrzebują wychowania ( $\mathrm{w}$ sensie odczuwania potrzeby wychowania); wykorzystuja wychowanie swoich dzieci do tego, aby móc im przekazać dalej cierpienia zadane im samym w dzieciństwie;

- zamiast wychowania postuluje się postawę towarzyszenia i wspierania związaną z szacunkiem, respektem, tolerancją i gotowością dorosłych do nauki" ${ }^{20}$.

Każda z powyższych tez dowodzi, że w koncepcji homo non educandus odrzuca się wychowanie jako swoistą wartość. Fundamentem

17 E. von Braunmühl, Antipaedagogik - Studien zur Abschaffung der Erziehung, Weinheim - Basel 1988.

18 H. von Schoenebeck, Antypedagogika w dialogu. Wprowadzenie w rozmyślanie antypedagogiczne, tłum. D. Sztobryn, Toruń 1991.

19 K. Rutschky, Schwarze Pädagogik - Quellen zur Naturgeschichte der bürgerlichen Erziehung, Frankfurt a.M. - Berlin 1988.

20 H. Berner, Wspótczesne kierunki pedagogiczne, w: Pedagogika, t. 1: Podstawy nauk o wychowaniu, red. B. Śliwerski, Gdańsk 2006, s. 237. 
aksjologicznym tej koncepcji jest wolność widziana jako autonomiczna siła człowieka, jako jego zdolność do rzekomego panowania nad samym sobą i otaczającym go światem. Tymczasem wolność, będąc znamienitym atrybutem człowieka, funkcjonuje w nader kruchej egzystencjalnej naturze człowieka. Stąd kwestia wolności jako wartości staje się zasadniczym problemem edukacyjnym ${ }^{21}$.

W czasach kryzysu, transformacji, integracji i globalizacji świata wolność, jako jedna z najważniejszych wartości ogólnoludzkich, zaczyna tracić swój prawdziwy sens, ulega deformacji w swej treści i staje się wcale nierzadko antywartością. Dzieje się tak dlatego, że wolność pojmowana jest coraz częściej relatywnie, sytuacyjnie i uznaniowo. Paradoksem wolności jest to, że jedni pojmują ją jako atrybut człowieka w kategoriach „wolności prawdziwej”, „twórczej”, „wzniosłej”, „szlachetnej”, inni postrzegają wolność jako przejaw „nieskrępowania”, „uwolnienia od wszelkich ograniczeń”, „przewrotności” czy wręcz „rozpasania”. I w tym miejscu rodzi się pytanie: czyżby zwolennicy homo non educandus nie zdawali sobie sprawy z zagrożeń jakie niesie ze sobą ich radykalna antyteza pozostająca w opozycji do tradycyjnej pedagogicznej koncepcji człowieka jako istoty potrzebującej wychowania?

Wolność „bez ograniczeń” staje się kluczowym problemem całej rzeczywistości społecznej, zwłaszcza w kontekście coraz bardziej odczuwalnej brutalizacji życia wśród dzieci i młodzieży szkolnej. Powszechnym zjawiskiem w tym środowisku staje się dyskryminacja, poniżanie, ośmieszanie, izolowanie, wykluczanie z zespołu, eliminowanie, nękanie, zastraszanie, przemoc fizyczna, znęcanie się psychiczne, agresja, mobbing, a nawet stalking, który polega na wzbudzaniu poczucia zagrożenia i naruszaniu prywatności.

Gdy próbujemy znaleźć szerszą odpowiedź na pytanie czym jest i na czym polega wolność w procesie wychowania, musimy najpierw się zdać na przyjęcie założenia, że jawi nam się ona w dwóch zależnych od siebie wymiarach, a mianowicie postrzegamy ją jako wolność zewnętrzną i wolność wewnętrzną wszelkich działań pedagogicznych. Obie te „wolności” przyjmują postać „wolności od...” i „wolności do...”.

21 Por. A.M. de Tchorzewski (red.), Wolność jako wartość i problem edukacyjny, Bydgoszcz 1999. 
W pierwszym przypadku możemy mówić o wolności od narzucania celów i programów wychowawczych, a także od ograniczeń, wymagań i ingerencji w treści głoszonych prawd i poglądów, od wszelkich prób indoktrynacji, którą posługują się chętnie różne ośrodki i centra państwowe i polityczne.

W drugim przypadku możemy mówić o wolności pedagogicznej do nieskrępowanego kreowania własnych programów i form ich realizacji, do nieskrępowanego głoszenia zasad, norm i prezentowania takich postaw, które nie tylko nie naruszają powszechnie uznane zasady życia społecznego, lecz wyraźnie przyczyniają się do rozwoju psychicznego, intelektualnego i moralnego dzieci i młodzieży. „Wolność do" przysługuje rodzinie i szkole, zaś przede wszystkim każdemu człowiekowi.

Wolność należy traktować jako swoiste pryncypium pedagogiczne dla działań wychowujących i wychowywanych, którzy zawsze tworzą wyjątkową wspólnotę niemającą sobie równej wśród innych wspólnot. Wolność jest więc zasadą i naturalnym ich żywiołem.

Wolność $\mathrm{w}$ procesie wychowania nie ma i nie może mieć nic wspólnego $\mathrm{z}$ samowolą; jest ona ściśle powiązana $\mathrm{z}$ odpowiedzialnością, stąd o wolności pedagogicznej mówimy jako o wolności odpowiedzialnej. Wolność odpowiedzialna jest kategorią aksjonormatywną, bowiem $\mathrm{z}$ jednej strony pozwala określić poziom etycznego postępowania będącego rezultatem kierowania się przez człowieka wolnością, zaś z drugiej strony umożliwia ocenę jego czynów i ich skutków z możliwością nakładania różnorodnych sankcji. Wolność pedagogiczna stanowi fundament wychowania, którego podstawą są wolność psychologiczna, wolność naturalna i wolność społeczna ${ }^{22}$.

Dzięki wolności psychologicznej wychowanie staje się działaniem nieskrępowanym, uwolnionym od nacisków i przymusu zewnętrznego, staje się działaniem wewnętrznie samodzielnym i umotywowanym.

Wolność naturalna dotyczy osobowej godności człowieka, która budowana jest na wpisanym w jego rozumną naturę obiektywnym ładzie moralnym. Wolność ta łączy się ściśle ze światem wartości

22 Por. T. Ślipko, Trojakie oblicze wolności, w: Wolność jako wartość i problem edukacyjny, red. A.M. de Tchorzewski, Bydgoszcz 1999, s. 11-14. 
moralnych, wśród których na szczególną uwagę zasługują te, które stanowią źródło powinności i obowiązków moralnych rodziców i nauczycieli. Wolność naturalna wzmacnia ich sprawności moralne, zwłaszcza autokreatywność, samodyscyplinę i sumienność.

Pod pojęciem wolności społecznej mieszczą się takie jej formy, jak wolność sumienia i religii, wolność myśli i słowa, wolność obywatelska ${ }^{23}$. Te formy wolności przysługują każdej osobie, każdemu rodzicowi i nauczycielowi, zaś wszelkie próby ich ograniczania należy widzieć w kategoriach zniewolenia.

Pedagogiczna wolność to wolność odpowiedzialna, posiadająca moc, dzięki której umysł i wola, kierując się podstawowymi wartościami i sprawnościami moralnymi, wpływają na bieg i jakość procesu wychowania, czyniąc go procesem autentycznym.

Zaprzeczeniem wolności odpowiedzialnej jest pseudowolność, czyli wolność, która przyjmuje zewnętrzną jej formę, lecz w gruncie rzeczy pod jej osłoną naruszany zostaje porządek wartości moralnych, ma miejsce lekceważenie powinności etycznych i zobowiązań społecznych. W takich sytuacjach mamy do czynienia ze zjawiskiem aberracji cech i właściwości autentycznej wolności. W porę niedostrzeżone, nieuchwycone, nieograniczone, czy wręcz niezlikwidowane odchylenia powodują przekształcanie się wolności odpowiedzialnej w antywychowawczą wolność „dwulicową",,,niegodziwą”, czy wręcz libertyńską, czyli sceptyczną i skierowaną przeciw racjonalnej strategii pedagogicznej.

\section{Typy strategii wychowawczych i ich właściwości}

Każde świadome i perspektywiczne działanie człowieka lub instytucji czy organizacji, zmierzające do osiągnięcia zakładanego celu, opiera się z reguły na przemyślanej strategii. W klasycznym ujęciu Ricky'ego W. Griffina strategia jest kompleksowym planem osiaggania celów organizacji ${ }^{24}$. Rzeczywistość i praktyka pedagogiczna, na które składają się czynności, proces i rezultaty wychowawcze, aby były sprawne i skuteczne, odwołują się do strategii, które są podstawą różnych stylów wychowawczych. Termin „strategia pedagogiczna”

23 Tamże, s. 14.

24 Por. R.W. Griffin, Podstawy zarzadzania organizacjami, tłum. M. Rusiński, Warszawa 2004, s. 245-246. 
może zatem oznaczać kompleksowy projekt założeń ideowych i teoretycznych oraz możliwości praktycznych, które mają gwarantować optymalizację zamierzonych działań wychowawczych. Strategia pedagogiczna to pewien rodzaj sztuki ,uprawiania wychowania”, zarówno w odniesieniu do jego całości, jak i poszczególnych fragmentów.

Analiza literatury należącej do nauk o wychowaniu pozwala wyodrębnić przynajmniej dwa zasadnicze typy strategii pedagogicznych. Jeden z nich można nazwać autokratycznymi, drugi zaś demokratycznymi. Różnice zachodzące pomiędzy nimi ukazuje poniższe zestawienie tabelaryczne.

\begin{tabular}{|l|l|}
\hline \multicolumn{2}{|c|}{ TYPY STRATEGI WYCHOWAWCZYCH } \\
\hline \multicolumn{2}{|c|}{ Rodzaje/cechy strategii pedagogicznych } \\
\hline \multicolumn{2}{|c|}{ FORMACYJNE } \\
\hline absolutystyczna & efektywna \\
apodyktyczna & konsekwentna \\
arbitralna & pomysłowa \\
autorytatywna & pozbawiona przymusu \\
despotyczna & racionalna \\
dyktatorska & rozważna \\
niedemokratyczna & rzeczowa \\
paternalistyczna & sprawna \\
woluntarystyczna & wolnościowa \\
\hline
\end{tabular}

Tabelal.

Typy i rodzaje/ cechy strategii pedagogicznych (oprac. własne)

Wymienione rodzaje poszczególnych typów strategii wychowawczych pozwalają uchwycić zasadnicze różnice zachodzące pomiędzy nimi. Ich cechy bardziej szczegółowe w ramach obu typów, a także rodzajów, mogą w różnym stopniu i z różną siłą się łączyć, przy czym $\mathrm{z}$ reguły przynajmniej jedna $\mathrm{z}$ nich będzie $\mathrm{z}$ reguły miała charakter dominujący lub przynajmniej wiodący.

Autokratyczna strategia wychowawcza ma charakter instrumentalny. Jej istotą jest urabianie przez wychowujących (rodziców i nauczycieli) w wychowywanych (dzieciach i uczniach) pożądanych cech, zachowań i postaw według ustalonych wzorców osobowych. Urabianie rozumie się tu jako bezpośrednie wpływanie i oddziaływanie wychowawcze, jako podporządkowanie podmiotów wychowywanych woli podmiotów wychowujących, którzy w swoim postępowaniu pedagogicznym kierują się z góry przyjętymi przez siebie zasadami i regułami. Strategia ta zakłada sterowanie wychowankami 
dla „ich dobra”, które znają i określają wychowujący. Od dziecka-ucznia oczekuje się zachowań i postępowania zgodnego z oczekiwaniami i zaleceniami rodziców-nauczycieli.

Formacyjną strategię wychowawczą cechuje podejście humanistyczne. Podejście to wyrasta z przeświadczenia wychowujących o potrzebie uznania podmiotowości wychowywanych, czyli akceptacji ich autonomii i indywidualności. Strategia ta polega na wspieraniu rozwoju dziecka-ucznia, na pomocy w rozpoznawaniu przez niego samego własnych możliwości w procesie samorealizacji. Służy temu interakcyjna komunikatywność wyrażana w dialogicznym porozumiewaniu się i wzajemnym zrozumieniu podmiotów wychowujących i wychowywanych.

W obu strategiach wychowawczych istotną rolę odgrywa dobór metod wychowawczych ${ }^{25}$. Do ważnych metod wychowawczych należą metody transfiguracyjne, czyli sposoby jakimi posługują się wychowujący w różnych przestrzeniach wychowawczych, opiekuńczych, edukacyjnych - szkolnych i pozaszkolnych (np.: zabawa, czas wolny, rekreacja, sport, turystyka) oraz w kontaktach z pozaosobowymi instrumentami masowego komunikowania się (radio, telewizja, prasa, książki, czasopisma) oraz wytwarzanymi przez różne technologie informatyczne (telefonia komórkowa, Internet, tablety itp.), które generują zachowania i postawy współczesnych dzieci i młodzieży.

\section{Ontologiczny status imperatywu pedagogicznego i jego znaczenie}

Pedagodzy-teoretycy i praktycy zajmują zróżnicowane stanowiska na temat znaczenia i roli imperatywów wychowawczych w procesie wychowania. W ramach wszystkich metod wychowawczych jakimi posługują się rodzice i nauczyciele, bez względu na to czy w ich dzialaniach pedagogicznych dominują strategie autokratyczne, czy też racjonalne, odwołują się oni, mniej lub bardziej świadomie, do różnych pod względem treści i zakresu imperatywów wychowawczych.

Imperatyw pedagogiczny to zrozumiale określony/wyartykułowany przekaz wychowujących, który komunikuje wychowankom o konieczności ich zachowań i postępowania, zgodnych ze społecznie

25 Por. A.M. de Tchorzewski, Wstęp do teorii wychowania, Kraków 2016, s. $138-147$. 
akceptowanymi i respektowanymi normami oraz oczekiwaniami. Przekaz imperatywu pedagogicznego dokonuje się na drodze werbalnej oraz poprzez samą postawę wychowującego w konkretnych sytuacjach wychowawczych. Rodzice i nauczyciele wyjaśniają i uzasadniają potrzebę takich a nie innych zachowań bądź postępowania dziecka/ucznia, informują go o oczekiwaniach w tym zakresie i wskazują jego znaczenie w kształtowaniu relacji do samego siebie, jak i względem innych osób.

Imperatyw pedagogiczny, mimo swej nazwy, nie może być kojarzony ani przez wychowujących, ani przez wychowywanych z przymusem ${ }^{26}$. Przymus bowiem uwłacza godności osobowej rozumianej jako niezniszczalna, immanentna właściwość wrodzona, świadcząca o człowieku jako wartości autotelicznej, przysługująca każdemu człowiekowi. Przymus narusza indywidualne poczucie człowieka o byciu kimś ważnym, uprawnionym do wolności i korzystania z praw jemu przysługujących ${ }^{27}$. Imperatyw wychowawczy stoi w całkowitej sprzeczności do przymusu będącego fenomenem w samym sobie negatywnym, którego następstwem w przypadku wychowywanych jest rodzące się w nich poczucie niezadowolenia, brak przekonania co do jego słuszności, rodzący się w nich bunt, wyzwalający reakcje „obronne”.

Tymczasem imperatyw pedagogiczny nie ma zmuszać do czegoś czy czegokolwiek, a jedynie wyzwalać wewnętrzną dyspozycyjność wychowanka ${ }^{28}$. Dyspozycyjność wychowanka jest odpowiedzią na oczekiwania wychowujących wobec takich zachowań i postępowania, które są powszechnie akceptowane i uznawane jako normy obowiązujące w różnych kontekstach rzeczywistości społecznej. Oto przykłady imperatywów wychowawczych.

26 Termin „imperatyw kategoryczny” wprowadził do języka filozofii i etyki Immanuel Kant, który w rozprawce O pedagogice (1803) sprzeciwiał się karom fizycznym.

27 Por. A.M. de Tchorzewski, Metafizyka i doświadczanie godności, w: Godność jako wartość i problem edukacyjny, red. I. Jazukiewicz, A.M. de Tchorzewski, Szczecin 2016, s. 19-34.

28 Por. S. Owen, Education Affairs, Boston 1989, s. 177. 


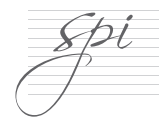

Diagram 1.

Imperatywy

wychowawcze

(oprac. własne)

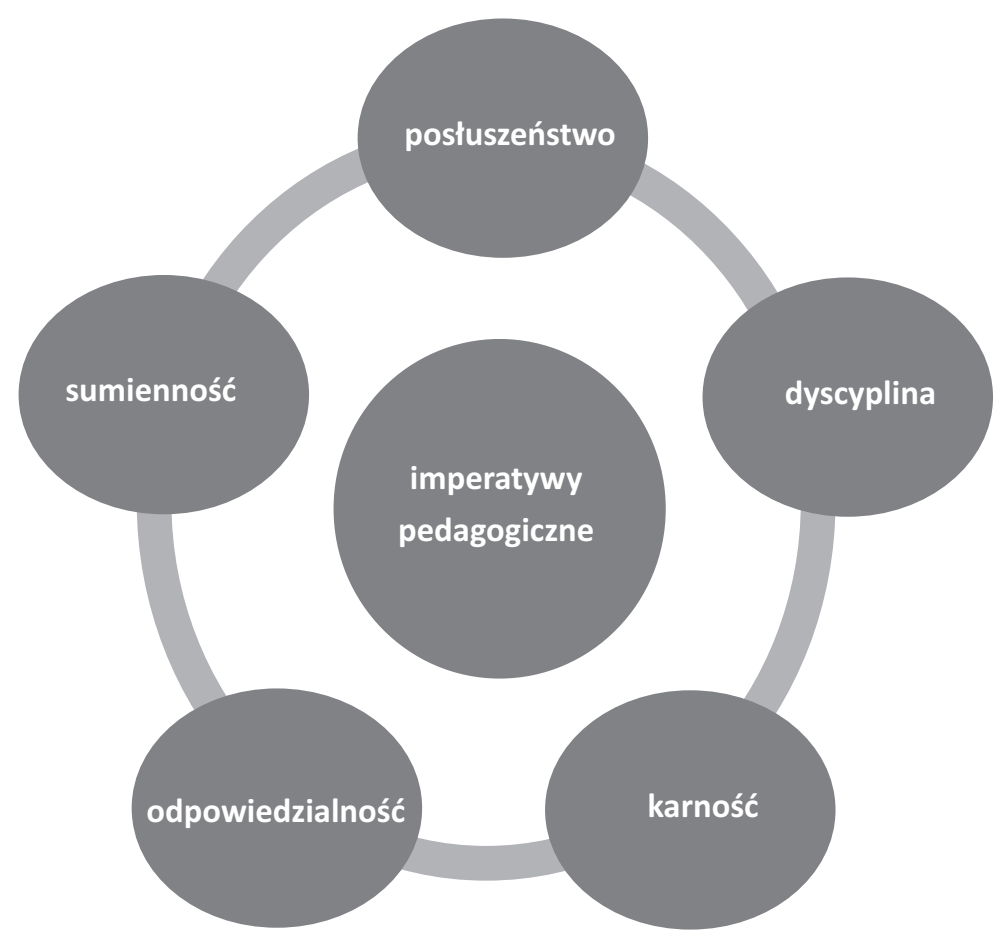

Wskazane w diagramie nazwy imperatywów wychowawczych mają znamiona synonimów, chociaż w gruncie rzeczy nie są i nie muszą nimi być. Każdemu można przypisać jednostkową treść i w ten sposób ukazać zachodzące pomiędzy nimi różnice.

Posłuszeństwo jako imperatyw pedagogiczny ma skłaniać wychowywanego do ustępliwości względem innych, kiedy ta dla jego dobra okazuje się konieczna. Warunkiem zaistnienia zachowań wychowanka mających znamiona tego imperatywu jest jego osobiste przekonanie o zasadności takiej postawy. Posłuszeństwo wprowadza w życie wychowanka ład, z którego roli i znaczenia zdaje on sobie w pełni sprawę, wiedząc, że służy on jego bezpieczeństwu, rozwojowi społecznemu i moralnemu. Posłuszeństwo jest wyrazem uznania przez wychowanka oczekiwań wychowującego. Posłuszeństwo odnosić należy zawsze do kogoś lub wobec kogoś, czyli wychowujących. Kieruje 
ono wychowanka ku zasadnej ustępliwości. Ustępliwość przygotowuje wychowanka w dorosłości do bycia posłusznym nakazom sumienia oraz do respektowania prawa obowiązującego we wspólnocie, do której należy.

Dyscyplina jest tym imperatywem pedagogicznym, do którego odwołują się wychowujący wówczas, kiedy zachodzi konieczność przywołania wychowanka do zachowań zgodnych ze znanymi mu normami współżycia społecznego. Dyscyplina ma chronić wychowanka przed zagrożeniami, których on sam może być sprawcą i ofiarą. Nie chodzi tu o pouczanie czy umoralnianie, ani o karanie wychowanków, lecz o jasne i zrozumiałe napiętnowanie ich zachowań nagannych i ukazywanie, a nawet ponoszenie konsekwencji jakie wynikają z zachowań nieadekwatnych do oczekiwań wychowujących. Dyscyplina jako imperatyw pedagogiczny ma wdrażać wychowanka do podporządkowania się normom regulującym stosunki wewnątrz zbiorowości, organizacji czy grupy społecznej. Dyscyplina w rodzinie odnosi się do przestrzegania w niej ładu i utrzymania przez wszystkich jej członków porządku, który zostaje ustalony przez rodziców. Szkolną dyscyplinę wyznacza się przez regulamin uczniowski, do przestrzegania którego są zobligowani uczniowie, a egzekutorami którego są nauczyciele i wychowawcy, rady pedagogiczne i rady rodziców oraz dyrekcje szkół. W organizacjach dziecięcych i młodzieżowych jej zasady opisane są w statutach określających prawa i obowiązki członków. Hierarchiczny układ tych organizacji umożliwia dyscyplinowanie wszystkich względem siebie. Dzięki temu upowszechniane i wdrażane są zasady postępowania, regulujące stosunki wewnętrzne takich zbiorowości.

Karność to imperatyw pedagogiczny, który wiąże się z wdrażaniem wychowanka do samodyscypliny poprzez samokontrolę i samoocenę własnego postępowania. Imperatyw ten wymaga od wychowanka orientacji w zakresie obowiązujących w społeczeństwie najważniejszych norm moralno-etycznych, ich zrozumienia i niczym nie wymuszonej gotowości do kierowania się nimi w życiu. Karność jest postawą konsekwentnego zachowania się wychowanka w każdej sytuacji, czemu towarzyszy przeświadczenie o doniosłości, znaczeniu i roli tych norm w procesie doskonalenia własnego rozwoju i swojej osobowości. „Kto strzeże karności, ten idzie ku życiu, kto gardzi 
upomnieniem - ku zatracie” (Prz 10,17). Karności nie należy utożsamiać z rygorem, „ślepym podporządkowaniem się” wychowanka, lecz ze świadomym przewidywaniem przez niego sankcji jakie mogą mieć miejsce w przypadku uporczywego łamania zasad, przepisów i obowiązujących norm postępowania.

Odpowiedzialność jako imperatyw pedagogiczny może być rozumiana jako gotowość wychowanka do ponoszenia konsekwencji za czyny, zachowania, postępowanie własne, jak i w stosunku do innych osób, ale także wobec różnych istot (zwierząt, roślin) oraz przedmiotów. Odpowiedzialność realizuje się zawsze na podłożu określonych wartości, stosunku do nich, naruszania ich lub urzeczywistniania ${ }^{29}$. Kształtuje ona także ważne cechy osobowościowe, takie jak: umiejętność podejmowania decyzji i kierowania swoim postępowaniem jako jego sprawca, samodzielne rozstrzyganie w zakresie ważnych decyzji życiowych i inne. Imperatyw ten ma na celu kształtować w wychowanku poczucie odpowiedzialności za siebie przed osobami odpowiadającymi za jego wychowanie i rozwój, ma on także kierować wychowanka ku postawie brania odpowiedzialności za siebie, ukazywać konsekwencje uchylania się od odpowiedzialności, zrzucania jej na innych oraz obarczania nią innych osób. Wychowanek winien zdawać sobie sprawę, że odpowiedzialność zawsze dotyczy tego, że jest się za coś i przed kimś odpowiedzialnym, zaś najważniejsze jest to, aby być odpowiedzialnym przed samym sobą, co powoduje osobiste ponoszenie odpowiedzialności ${ }^{30}$.

Sumienność jest imperatywem pedagogicznym, który ma kierować wychowanka ku zdolnościom oceny własnych działań, zachowań i postępowania przez odwoływanie się do etycznych pojęć dobra i zła oraz aprobowanej hierarchii wartości ${ }^{31}$. Sumienność wychowanka wyrażają jego cechy, takie jak: pracowitość, rzetelność, obowiązkowość, punktualność, porządek itp. Sumienność należy postrzegać jako element procesu kształtowania sumienia

29 Por. M. Michalik, Istota odpowiedzialności, w: Odpowiedzialność jako wartość i problem edukacyjny, red. A.M. de Tchorzewski, Bydgoszcz 1998, s. 19-44.

30 Por.: R. Ingarden, Książeczka o cztowieku, Kraków 1972; A.M. de Tchorzewski, Wieloptaszczyznowa odpowiedzialnośc nauczyciela, w: Odpowiedzialność jako wartość i problem edukacyjny, dz. cyt. s. 89-100.

31 Por. A.E. Gała, Uwarunkowania wychowawcze dojrzatej moralności, Lublin 1992, s. 25. 
wychowanka. Sumienie zaś jest sądem rozumu człowieka o własnym postępowaniu. Sumienność, będąca zdolnością pozwalającą ocenić własne postępowanie jako zgodne $\mathrm{z}$ przyjętymi normami moralnymi, czyni wychowanka uczciwym, rzetelnym, prawdomównym człowiekiem, którego wiarygodność staje się jego trwałą cechą nazywaną prawością.

Imperatywy pedagogiczne nie mogą w żaden sposób naruszać praw wychowanków. Wiele z nich zostało opisanych przez pedagogów minionych, jak i współczesnych czasów ${ }^{32}$. Prawa te znajdują również swoje odzwierciedlenie w różnych dokumentach międzynarodowych. Wśród nich do trzech najważniejszych zaliczyłbym:

- prawo wychowanka do szacunku;

- prawo wychowanka do dialogu $\mathrm{z}$ dorosłymi;

- prawo wychowanka do błądzenia i radosnego dążenia do poprawy.

Żadne z tych praw nie musi wykluczać odwoływania się do imperatywów wychowania. Mogą one służyć lepszemu zrozumieniu własnych praw wychowanka oraz zdawaniu sobie w pełni sprawy, że oprócz nich ciążą na nim także - stosownie do wieku i poziomu rozwoju - obowiązki i powinności. Imperatyw wychowania w autentycznym procesie wychowania, w którym wychowywani i wychowujący stanowią jego podmioty, może spełniać funkcje hamowania i równowagi w dochodzeniu do indywidualnej dojrzałości.

\section{Imperatyw wychowawczy a sprawności wychowanka}

Każdy konkretny imperatyw wychowawczy można uznać za swoisty środek kształtujący sprawności wychowanka w zakresie zasadniczych wymiarów/obszarów jego wielostronnego rozwoju. Chodzi tu o sprawności fizyczne, psychiczne, intelektualne oraz moralne. To właśnie one stanowią szczególnie ważne przestrzenie procesu wychowania.

„S prawności fizyczne - wiążą się z kategorią zdrowia; to pożądany stan zdrowia człowieka, który umożliwia optymalne funkcjonowanie gwarantujące zdolność do samodzielnego i niczym nie ograniczonego życia odpowiednio do poziomu rozwojowego i wieku.

32 Por. A. Tchorzewski (red.), Życie i twórczośc Janusza Korczaka jako temat filozoficzno-pedagogicznej refleksji, Bydgoszcz 1979, s. 8. 
Sprawności psychiczne - wiążą się z pojęciem psychiki i przeżyciami psychicznymi; sprawności psychiczne odnoszą się do stanu świadomości i jej treści, które wyrażają się w myślach, marzeniach, pragnieniach odczuwanych przez człowieka, z których zdaje on sobie sprawę.

Sprawności intelektualne - wiążą się z takimi kategoriami, jak wiedza, erudycja, mądrość, które decydują o otwartości rozumu, zdrowym rozsądku, przenikliwości umysłu, krytycyzmie, dzięki którym człowiek pragnie poznawczo oswajać otaczający go świat.

S prawności moralne, przez które można rozumieć niezawodność w postępowaniu, która jest relacją skierowaną na zewnątrz podmiotu działającego, wyraża się w dążeniu człowieka do dobrego działania, to także trafność decyzji moralnych według pewnego porządku dóbr, to powinność, gdzie wartość ma charakter instrumentalny; to postępowanie, ale także walka, w której pokonuje się namiętności, to aktywna wola człowieka skierowana na dobro"33.
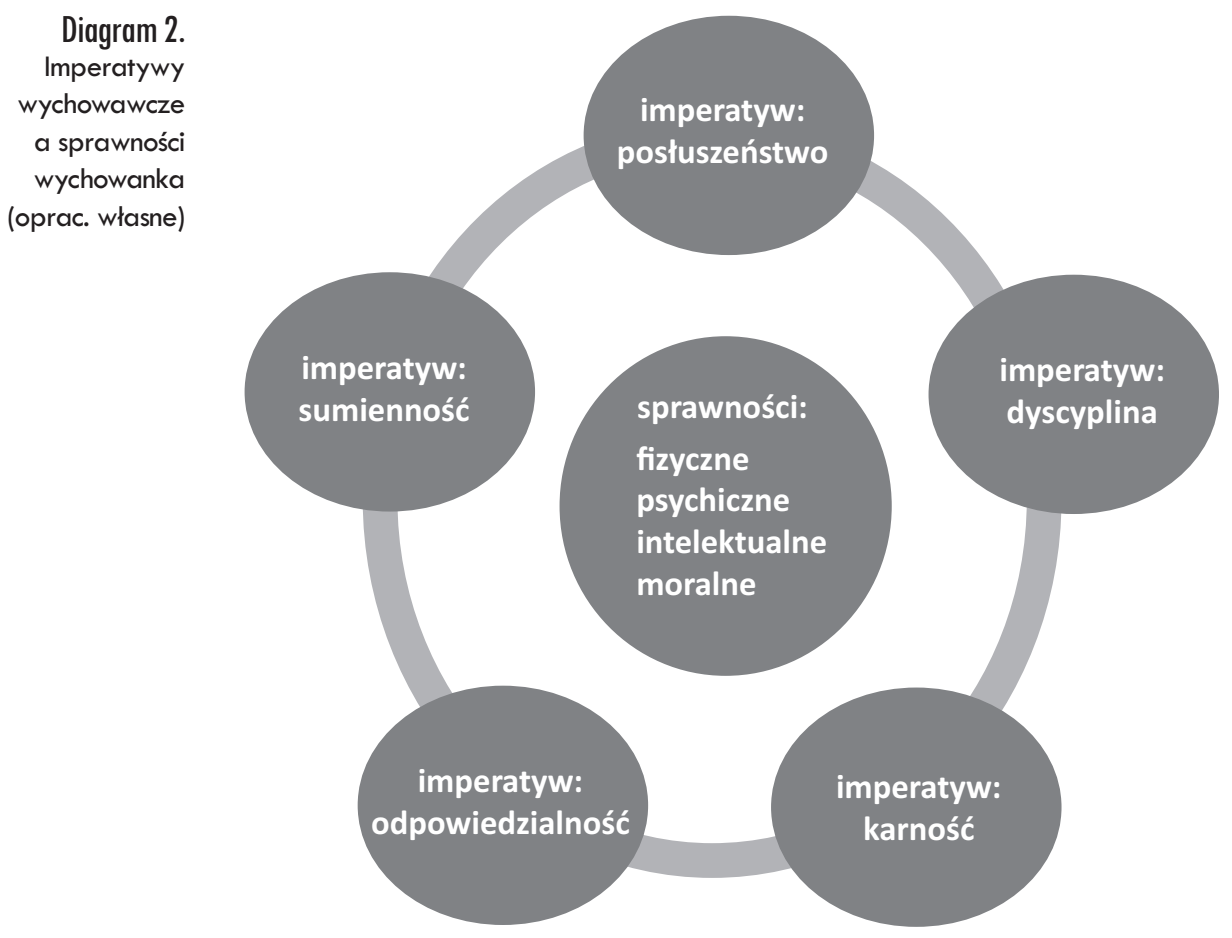

33 A.M. de Tchorzewski, Wstęp do teorii wychowania, dz. cyt., s. 203-204. 
Kształtowanie wymienionych sprawności jest procesem zintegrowanym, chociaż wewnętrznie złożonym. Na każdym etapie życia, w każdej fazie rozwojowej wychowanka poszczególne imperatywy mogą odgrywać - jako środki pedagogiczne - większą lub mniejszą rolę. W zależności od konkretnych sytuacji wychowawczych mogą być bardziej lub mniej uwyraźniane i zdynamizowane. Chodzi jednak o to, aby za ich pomocą dochodzić do określonych rezultatów.

Wymienione przykładowo imperatywy pedagogiczne związane są z określonymi cnotami moralnymi, a tym samym z całościowym rozwojem człowieka. Należy zdać sobie sprawę, że te są w coraz większym stopniu wypierane lub też zastępowane przez inny świat wartości, tj. pieniądz, pracę i władzę. Powoduje to coraz szybsze poszerzanie się przepaści pomiędzy troską o sprawność moralną człowieka a światem społecznym.

Ważne jest zatem, aby w procesie wychowania dostrzegać znaczenie i rolę imperatywów pedagogicznych, dzięki którym:

- potwierdza się ważność moralnych, etycznych i duchowych wymiarów rozwoju wychowanka;

- odchodzi się od instrumentalnej wizji wychowania na rzecz wizji humanistycznej, która ma służyć człowiekowi poprzez poszukiwanie i zrozumienie sensu jego osobistego i społecznego życia;

- umożliwia się wychowankowi poznawanie siebie samego oraz innych bez potrzeby empirycznego doświadczania (zasada immanencji i transcendencji);

- działania wychowawcze zmierzają w kierunku reintegracji systemu wartości i ich hierarchizacji.

Rolą imperatywów pedagogicznych w każdej strategii wychowawczej winno być zawsze hamowanie tego, na co nie ma zgody i przyzwolenia oraz zmierzanie do osiągania stanu równowagi w złożonym procesie rozwoju każdego wychowanka.

\section{Podsumowanie}

1. Imperatyw pedagogiczny służyć ma całościowemu rozwojowi wychowanka.

2. Świadome odwoływanie się do niego ma zapobiegać rodzącej się przepaści pomiędzy troską o różne, ale ważne sprawności wychowanka a współczesnym światem społecznym, który cechuje chaos aksjonormatywny. 
3. Imperatyw pedagogiczny nie służy wąsko rozumianej, instrumentalnej wizji wychowania. Nie zagraża on w żadnym razie potencjałowi jaki tkwi w wychowanku, nie ogranicza go w rozwoju i w żadnym przypadku nie może się przyczyniać do ubezwłasnowolnienia wychowanka.

4. Właściwie rozumiany imperatyw pedagogiczny jest środkiem działania komunikacyjnego w relacji wychowujący - wychowywany.

5. Dzięki imperatywom pedagogicznym, do których odwołuje się wychowawca w demokratycznej strategii wychowawczej (w przeciwieństwie do autokratycznej), wychowanek świadomie weryfikuje swoje zachowania i postępowanie. Tym samym w sposób bardziej samodzielny i dojrzały uczestniczy w świecie społecznym i życiu osobistym.

Imperatyw pedagogiczny jako środek wychowania ma w intencjonalnym procesie wychowania wspomagać wychowanka $\mathrm{w}$ rozwoju i osiąganiu dojrzałości do rozwiązywania jednostkowych i osobistych zadań oraz problemów życiowych. Ma służyć interakcjom międzyludzkim ukierunkowanym na dobro człowieka, który panuje nad swoim życiem i poszukuje w nim sensu, ma kształtować jego sprawności, zwłaszcza sprawności moralne.

\section{Bibliografia}

Berner H., Wspótczesne kierunki pedagogiczne, w: Pedagogika, t. 1: Podstawy nauk o wychorwaniu, red. B. Śliwerski, Gdańskie Wydawnictwo Psychologiczne, Gdańsk 2006.

Bińczycka J., Między swobodq a przemocq w wychowaniu, Oficyna Wydawnicza „Impuls”, Kraków 1999.

Braunmühl E. von, Antipaedagogik - Studien zur Abschaffung der Erziehung, Beltz, Weinheim - Basel 1988.

Czerny J., Filozofia wychowania, Wydawnictwo „Śląsk”, Katowice 1997.

Czubek J., Wybór dziet pisarzy greckich i tacinskich, Zakład Narodowy im. Ossolińskich, Lwów 1902.

Dobson J., Zasady nie sa dla tchórzy. Jak zachować równowagę między mitościq a dyscyplina w wychowaniu dzieci, tlum. U. Kowalczyk, Vocatio, Warszawa 1993.

Erazm z Rotterdamu, Pochwata gtupoty, w: Źródta do dziejów wychowwania i myśli pedagogicznej, t. 1, Wyboru dokonał i opracował S. Wołoszyn, PWN, Warszawa 1965, s. 219-223. 
Faber A., Mazlish E., Jak mówić żeby dzieci nas stuchaty. Jak stuchać żeby dzieci do nas mórwity, tłum. M. Więznowska, Media Rodzina, Poznań 1993.

Gała A.E., Uwarunkowania wychowawcze dojrzatej moralności, Katedra Psychologii Wychowawczej KUL, Lublin 1992.

Griffin R.W., Podstawy zarzqudzania organizacjami, tlum. M. Rusiński, Wydawnictwo Naukowe PWN, Warszawa 2004.

Gordon T., Wychowanie bez porażek, tłum. A. Makowska, E. Sujak, PAX, Warszawa 1991.

Historia wychowania, t. 1, red. Ł. Kurdybacha, PWN, Warszawa 1965.

Janczynowska M., Historia starożytnego Rzymu, PWN, Warszawa 1986.

Kaja B.M., Psychologia wspomagania rozwoju. Zrozumié́ świat życia człowieka, Gdańskie Wydawnictwo Psychologiczne, Sopot 2010.

Kot S., Historia wychowania. Zarys podręcznikowy, Państwowe Wydawnictwo Książek Szkolnych, Kraków 1924.

Krauser W.H., Diktat und Erziehung, [b.w.], Berlin 1991.

Michalik M., Istota odpowiedzialności, w: Odpowiedzialnośc jako wartość i problem edukacyjny, red. A.M. de Tchorzewski, Wydawnictwo „Wers”, Bydgoszcz 1998, s. 19-44.

Mitek M., Pedagogika dla teologów, Wydawnictwo Świętego Krzyża, Wroclaw 2002.

Owen S., Education Affairs, [b.w.], Boston 1989.

Rutschky K., Schwarze Pädagogik - Quellen zur Naturgeschichte der bürgerlichen Erziehung, Ullstein, Frankfurt a.M. - Berlin 1988.

Seidel P., Erziehung und Paedagogik, VS-Verlag, Wisbaden 1993.

Schoenebeck H. von, Antypedagogika w dialogu. Wprowadzenie w rozmyślanie antypedagogiczne, tłum. D. Sztobryn, UMK, Toruń 1991.

Sobczak J., Nowe Wychowanie w polskiej pedagogice okresu drugiej Rzeczypospolitej (1918-1939), Wydawnictwo Uczelniane WSP, Bydgoszcz 1998.

Szewczuk W., Świat wartości i wychowanie, Wydawnictwo Fundacja Innowacja, Warszawa 1996.

Ślipko T., Trojakie oblicze wolności, w: Wolnośc jako wartośc i problem edukacyjny, red. A.M. de Tchorzewski, Wydawnictwo „Wers”, Bydgoszcz 1999, s. 11-14.

Tchorzewski A.M. de (red.), Wolność jako wartośc i problem edukacyjny, Wydawnictwo „Wers”, Bydgoszcz 1999.

Tchorzewski A.M. de (red.), Życie i twórczośc Janusza Korczaka jako temat filozoficzno-pedagogicznej refleksji, Wydawnictwo Uczelniane WSP, Bydgoszcz 1979.

Tchorzewski A.M. de, Metafizyka i doświadczanie godności, w: Godność jako wartośc i problem edukacyjny, red. I. Jazukiewicz, A.M. de Tchorzewski, Wydawnictwo Naukowe US, Szczecin 2016.

Tchorzewski A.M. de, Wstęp do teorii wychowania, Akademia Ignatianum w Krakowie - Wydawnictwo WAM, Kraków 2016. 
Wołoszyn S., Dzieje wychowania i myśli pedagogicznej, PWN, Warszawa 1964.

Wybór tekstów źródtowych do historii wychowania. Wyboru dokonali J. Walczyna, S. Wołoszyn, PZWS, Warszawa 1962.

\section{ADRES DO KORESPONDENCJI:}

Prof. dr hab. Andrzej Michał de Tchorzewski Akademia Ignatianum w Krakowie

Wydział Pedagogiczny

Instytut Nauk o Wychowaniu

andrzejdetchorzewski1@wp.pl 